\title{
G. MATTEO ROCCATI, Chambéry, un centre mineur dans la production incunable
}

\author{
Maria Colombo Timelli
}

\section{OpenEdition}

\section{Journals}

\section{Édition électronique}

URL : https://journals.openedition.org/studifrancesi/31403

DOI : 10.4000/studifrancesi.31403

ISSN : 2427-5856

Éditeur

Rosenberg \& Sellier

\section{Édition imprimée}

Date de publication : 1 août 2020

Pagination : 381

ISSN : 0039-2944

\section{Référence électronique}

Maria Colombo Timelli, «G. matteo Roccati, Chambéry, un centre mineur dans la production incunable », Studi Francesi [En ligne], 191 (LXIV | II) | 2020, mis en ligne le 01 septembre 2020, consulté le 18 septembre 2021. URL : http://journals.openedition.org/studifrancesi/31403 ; DOI : https://doi.org/ 10.4000/studifrancesi.31403

Ce document a été généré automatiquement le 18 septembre 2021.

\section{(c) (i) (9) $\Theta$}

Studi Francesi è distribuita con Licenza Creative Commons Attribuzione - Non commerciale - Non opere derivate 4.0 Internazionale. 


\title{
G. MATTEO ROCCATI, Chambéry, un centre mineur dans la production incunable
}

\author{
Maria Colombo Timelli
}

\section{RÉFÉRENCE}

G. MATTEO ROCCATI, Chambéry, un centre mineur dans la production incunable, in Le comunità dell'arco alpino occidentale, a cura di F. Panero, Cherasco, Centro Internazionale di Studi sugli Insediamenti Medievali, 2019, pp. 237-253.

1 Sur la base du ISTC, G.M.R. offre un examen et un commentaire approfondi de la production de livres à Chambéry avant 1500 . Deux imprimeurs et six titres sont concernés: Antoine Neyret (quatre impressions entre 1484 et 1486) et l'imprimeur anonyme dit «du Breviarium Sedunense» (deux impressions, 1482-1486). L'intérêt de cet article, au-delà des précisions qu'il offre quant à la fabrication matérielle des ouvrages, tient à l'analyse de cette production, certainement limitée, en rapport avec celle des centres proches (Genève, Grenoble, et naturellement Lyon), et aux raisons qui peuvent expliquer, en amont, l'installation de deux éditeurs-imprimeurs dans ce centre de l'Isère, et, en aval, leur disparition en quelques années seulement. Leurs stratégies éditoriales sont certainement en cause: si Neyret opte pour des livres en français, illustrés, et pour des contenus religieux s'adressant à un public large, à côté d'un «roman» comme la mise en prose de Baudoin de Flandre, l'anonyme choisit au contraire d'imprimer des livres de sujet religieux et savant en latin. Dans les deux cas, la concurrence de centres autrement plus importants a eu raison de deux entreprises locales répondant à une demande certainement plus limitée. 